\title{
Community Social Polarization and Change: Evidence from Three Recent Studies
}

\author{
Max Stephenson Jr. *(D), Beng Abella-Lipsey, Lara Nagle and Neda Moayerian $(\mathbb{D}$ \\ Institute for Policy and Governance, Virginia Tech, Blacksburg, VA 24061, USA; lipseyb@vt.edu (B.A.-L.); \\ lkn4187@vt.edu (L.N.); mneda14@vt.edu (N.M.) \\ * Correspondence: mstephen@vt.edu; Tel.: +1-540-231-6775
}

Received: 22 April 2020; Accepted: 25 May 2020; Published: 29 May 2020

\begin{abstract}
This review article analyzes three major recent books (written by Robert Wuthnow, Arlie R. Hochschild, and James and Deborah Fallows, respectively) concerning ongoing political, economic and social change in United States' rural communities to probe differing frames and claims among them. We contend these works together point to vital social and political forces that must receive increased attention if the communities they treat are to address the challenges confronting them successfully. Thereafter, we briefly and illustratively underscore the significance of these authors' arguments using our own ongoing work in two small communities confronting catastrophic economic decline and social fissuring in Central Appalachia. Overall, we argue that an analytical approach that combines elements of Wuthnow's sensitivity to demographic and scalar polarization and divides, coupled with Hochschild's emphasis on opportunities to instill and call on empathetic imagination in development efforts, could assist these rural communities' residents to understand more fully the dynamics at play within them and to craft strategies aimed at addressing those challenges. In particular, we contend that the Fallowses' call for pragmatic interventions and partnership building must be accompanied by long-term efforts to overcome the fear engendered by the view that rural community life constitutes a consumerist zero-sum game, and the accompanying widespread belief in those jurisdictions that scapegoating and explicit or implicit racialized hierarchies represent reasonable responses to such anxieties.
\end{abstract}

Keywords: community change; praxis; rural communities; Central Appalachia; polarization; empathetic imagination; deep story

\section{Introduction}

In their book, Our Towns: A 100,000-mile Journey into the Heart of America, journalists James and Deborah Fallows contended that the deep polarization and conflict in our national and state politics today are not much in evidence at the local level [1]. The authors argued that in the communities across the United States they visited, leaders were working across sectors to secure development and revitalization without the rancor and partisanship at play at state and national scales: "people work together on practical local possibilities, rather than allowing bitter disagreements about national politics to keep them apart" [1] (p. 402).

In contrast, sociologist Robert Wuthnow recently published a decade-long exhaustive examination of rural American communities with populations of fewer than 25,000 people [2]. He argued that the inhabitants of those places perceive themselves as under attack from the "outside", and that the views underlying this perspective have exposed and exacerbated racial, cultural and partisan fault lines among their populations. Wuthnow found that rural citizens across the country were deeply concerned about the decline of what they perceived to be the moral fabric of their communities. Wuthnow also 
contended that race, racism and social hierarchies were never far from the surface in these small towns and that such beliefs provide fertile ground for possible conflict, discrimination and social cruelty.

Finally, sociologist Arlie Russell Hochschild, has offered an analysis of the views of a sample of rural Lake Charles, Louisiana, Tea Party sympathizers that sought to describe the well-springs of their frustration and anger, while arguing that compassionate listening provides a mechanism by which to bridge the "empathy wall" between their views and the perspectives of Americans from urban centers [3]. Her analysis stressed that the members of these communities, too, sought to preserve a prevailing social order that often exhibited a specific racial character in the face of ongoing environmental degradation and economic decline. Most of those she interviewed were disposed to loathe the national government, and at the state level, to elect Republican Party officials who had all but bankrupted that jurisdiction and allowed widespread pollution of their beloved bayous. Paradoxically, these Louisianans supported those leaders' claims that their actions would best ensure against government usurpation of residents' rights. Hochschild found that the opposite has obtained.

This paradox ran deep among the Louisiana citizens with whom Hochschild interacted for five years. The Lake Charles area residents whom Hochschild came to know exhibited a deep-seated angst associated with persistent economic precarity and an ongoing decline in their community's viability. They also evidenced a companion search for someone or something to blame for that situation. Perversely, Hochschild found that, partly as a result of conservative media and targeted corporate advocacy campaigns, the national government as an institution has often emerged as that scapegoat/target, even as that entity provides the principal wherewithal available to address many of the difficulties it is blamed for creating, failing to tackle or exacerbating.

\section{An Outline of Our Argument}

This review essay examines these differing frames and claims concerning ongoing political, economic and social change in United States' rural communities that we have found illuminating for our ongoing field work in two small Appalachian communities confronting catastrophic economic decline and social fissuring in Southwest Virginia and West Virginia, respectively. We review these three major recent works on community change in the United States and argue that an analytical approach that combines elements of Wuthnow's sensitivity to demographic and scalar polarization and divides, coupled with Hochschild's emphasis on opportunities to instill and realize empathetic imagination in development efforts, could assist these communities' residents to understand more fully the dynamics at play within them and to craft strategies aimed at addressing those challenges. In particular, we contend that the Fallowses' call for pragmatic interventions and partnership building must be accompanied by long-term efforts to overcome the fear engendered by the view that community life constitutes a consumerist zero-sum game and that scapegoating and explicit or implicit racialized hierarchies represent reasonable responses to such anxieties.

In many ways, as we parsed these studies of rural America and reflected on our own experience working in economically distressed communities in Central Appalachia, we came to believe that the Fallowses had principally examined one valence: the pragmatism of the residents of these towns. While that focus is important, they did not investigate deeply the social, political and cultural consequences of the conflicts and changes wrought by ongoing economic and social globalization and national political change for the communities they visited. No manner of intra-communal partnership building and asset mobilization of the sort the Fallowses chronicle can alone overcome the ongoing demographic and economic decline in many rural small towns. These must effectively solicit the support of other levels of government and external actors if they are to realize their aims and hopes, because they do not themselves possess adequate social or economic capital to overcome the challenges of overweening, and often global, economic change and its associated consequences. Nonetheless, especially for the citizenries of rural communities of 2000 or fewer inhabitants, residents' belief in self-reliance and their appropriate in-principle liberal skepticism of governmental power have caused them to respond to the political mobilization efforts of partisans willing to scapegoat government as the architect of their woes 
and who are just as willing, on ideological grounds, to deny those residents public support as they seek to address the changes that have beset them.

Accordingly, we argue that analysts may need to understand more fully the changing cultural firmament that can produce strong rural political support for local, state and national political figures who have often deepened fiscal budget woes and otherwise attacked public programs supporting those populations. Scholars must also help those groups understand that such is occurring, even as, paradoxically, those populations must rely on those governments, many already strained fiscally by such policies and broader trade and economic shifts, to support change.

In this sense, while the Fallowses', Wuthnow's and Hochschild's community samples overlapped to some degree, the latter two authors examined different parts of the proverbial elephant in that classic Indian fable than their counterparts. We contend that what is needed in initiatives to secure community change are efforts to ensure that the factors all of these authors investigated receive sustained attention and, more particularly, that cultural and social determinants are not set aside in favor of a narrow neoliberal view that pretends that these jurisdictions, especially the smallest and most rural of them, can alone develop future economic possibilities in their straitened circumstances. As a practical matter, this must be so, irrespective of community residents' predilection to support officials who offer such arguments. And, that orientation cannot change, at least in a democratic way, unless citizens themselves conclude that it must.

The future of these jurisdictions may well depend on broader recognition of this reality, not only among analysts and would-be community developers, but also among affected residents. Even as we note this imperative, we recognize the signal character of this challenge for populations that have witnessed the decline of their known and venerated way of life and who have seen many of their number move away, succumb to hopelessness and substance abuse disorders, or accept false panaceas and claims concerning their common challenges. Indeed, Wuthnow's interviewees shared a belief that a failing community is a collective reflection of each person living within it [2] (pp. 77-78). Nevertheless, abandoning an established view about one's community and oneself creates a fear-filled anxiety, especially if residents are convinced there is no counter-narrative worthy of replacing it [4].

\section{Analytical Frame}

To address our analytic aims for this review essay, we first briefly profile the arguments offered by these three important recent works concerning:

- The significance of moral community assumptions to understanding community change dynamics and

- the role of race and ethnicity, and more broadly, of alterity or difference as an organizing epistemic assumption in rural communities.

We seek as we do so to compare and contrast the findings of each of the analyses we profile concerning these matters.

Ultimately, and in keeping with our argument above, we suggest that students of rural community development may wish to rethink their models of change to include not only technical assistance or asset mobilization [1], but also how each of these and community imaginaries or ways of knowing [2,3] intersect to mediate the character and possibilities for local communal action. As a corollary, these works suggest that interested scholars should pay closer attention to how and why social imaginaries often create dissensus and stymie shared possible initiatives, requiring conflict amelioration and management in addition to mobilization for action-a central theme and preoccupation, especially, of the Wuthnow and Hochschild analyses discussed here. All of this said, we worry nonetheless whether some hard-hit rural jurisdictions will be able to find new economic niches in a global capitalist economy characterized by ongoing automation and swift technological change. We do not make this point to argue for inaction or to suggest that residents of these towns move away from the places in which they are rooted to find new opportunities. Instead, we emphasize this concern to highlight 
the fact that governments at all scales must play roles in any potential response to ongoing rural community challenges, and that ignoring the continued immiseration occurring in many such localities or pretending that they can address their difficulties alone offers their residents no hope at all.

\subsection{The Significance of Conceptions of Moral Community}

\section{The Fallowses' Argument Concerning Moral Community}

The Fallowses did not make rural citizen imaginaries of their communities a central focus of their book. To the extent they reached these matters, they did so indirectly as a part of their primary consideration of a jurisdiction's readiness to engage and to maintain public-private partnerships for change and, more sharply, in their conclusions. There, they took a shorter-term view and contended.

Despite the economic crises of the preceding decade and the social tensions of which every American is aware, most parts of the United States that we visited have been doing better, in most ways, than most Americans realize. Because many people don't know that. ... They feel even angrier about the country's challenges than they should, and are more fatalistic about the prospects of dealing with them. [1] (p. 12)

This contention notwithstanding, the authors also suggested that while many of the communities they visited have shown remarkable economic and social adaptability and resilience as the nation has recovered, however unevenly, from the "Great Recession" of 2007-2009, the United States is nevertheless in the midst of a fresh Gilded Age in which,

Old ways of life and sources of income vanish practically overnight.... For the technologies of this era: the prospect of all hours tracking and the perfection of the surveillance state; the economic assault on traditional news media and the intellectual elevation of rumors and disinformation; the increased pressures toward economic polarization; the rise of new monopolies and the use of their money and power to prevent their own regulation; and countless other challenges. [1] (p. 396)

The Fallowses argued in their conclusions that national politics was now poorly situated to take steps to address these difficult challenges and one of the nation's principal political parties, the Republican Party, "From Nixon onward, ... has channeled resentment about intellectual and cultural elites, as well as racial minorities, into support for the business elite. Thus, white voters in West Virginia or Kansas support tax policies that disproportionately benefit financiers in New York or San Francisco" [1] (p. 399).

The picture one obtains from the Fallowses concerning the role of local conceptions of community in change efforts is that residents of small towns and rural communities are pragmatically pushing ahead to do what they can, despite the inauspicious long-run trends in the political economy that suggest their efforts may be undone by larger economic and social forces, or employed in paradoxical ways for partisan mobilization that may work against their communities' relative sustainability and efficacy. It is also clear from their argument that the authors are aware that local action has limits and will not itself address the nation's largest looming challenges or repair the torn economic and social fabrics of the country's communities, rural and urban alike. Their hope seems to be that the rural citizenry will at some point wake to this governance situation and demand that their public leaders adopt an alternate course that employs political power more effectively to regulate economic institutions [1] (p. 398). They do not indicate how or why this might occur, except to note it will likely result from a dramatic and galvanizing event or events. Moreover, they do not address the proclivity of so many rural residents to vote for those ill-disposed to pursue this possibility, nor compare such a contention to the norms, values and mores of the communities they visited.

\section{Wuthnow's Argument Concerning Moral Community}

Wuthnow subtitled his book Decline and Rage in Rural America, and these were indeed primary foci of that volume. As he framed his thesis: 
My argument is that understanding rural America requires seeing the places in which its residents live as moral communities.... I mean it [this term] rather in the more specialized sense of a place to which and in which people feel an obligation to one another and to uphold the ways of being that govern their expectations about ordinary life and support their feelings of being at home and doing the right things. [2] (p. 4)

As he undertook interviews with citizens living in rural places and localities across the country, Wuthnow argued that they voiced a common perspective concerning the plight of their communities' moral outrage:

The moral outrage of rural America is a mixture of fear and anger. The fear is that small town ways of life are disappearing. The anger is that they are under siege. The outrage cannot be understood apart from the loyalties that rural Americans feel toward their communities. It stems from the fact that the social expectations, relationships, and obligations that constitute the moral communities they take for granted and in which they live year by year are being fundamentally fractured. [2] (p. 6)

Wuthnow contended that the realities of this fracture are particularly cruel. The number of individuals engaged in farming in the nation has been declining for decades, as have the populations and related economic vibrancy of many small towns located near farms. This has occurred as agriculture has mechanized and the acreage and general capitalization necessary to engage in farming competitively in a global market has risen. Other rural towns have lost their central economic anchors, whether textiles or furniture production, or timber, fisheries or mining-related extraction, with the advent of increased international competition, long-term unwise management of resources, and/or mechanization, displacement by more environmentally viable or less expensive alternatives or some mixture of these factors. This scenario, which in some rural communities has arisen in the space of less than a generation, leads naturally to shock and concern among such residents, and to those individuals asking, "'How can the problem be solved?'” [2] (p. 7) That disquiet in turn leads, Wuthnow observed, to "questions about who is to blame" [2] (p. 7).

Wuthnow contended that faced with a crumbling way of life and shared way of being in their communities, rural dwellers have turned first to one another to address what they take to be their common plight. They well know that they do not possess sufficient resources or capacity to reverse their community fates by themselves. In turn, they are outraged when they seek help from Washington, D.C., (or their state capitals) and they perceive either inaction or, in a competing narrative, "the government constantly intrudes in our lives without understanding us and thus makes our problems worse" [2] (p. 11).

This second trope is important, as it suggests that many rural residents increasingly feel besieged by broader social trends that do not align with their beliefs and values. This is occurring even as they perceive themselves as plagued by economic changes wrought by unseen agents and believe that this dual-barreled calamity is being deepened by federal government support. These shifts have included the advent of social media, the growth of popular entertainment and technology options that many rural residents fret are unhealthy for their children, and the extension of civil rights and social acceptance to gay individuals and other minorities. These developments also include a rapidly changing and markedly heterogeneous population that portends white males becoming a national minority, accepting individuals from different faith traditions, and so on. Recent national acceptance of homosexuality, particularly, has proven especially difficult for many rural residents, a significant share of whom believe in Christianity as the one true religion and the Bible as literal truth. Similarly, many are opponents of abortion rights for women, which a majority of other Americans continue to support.

Overall, as Wuthnow concluded,

When a moral order is threatened, the fact that it is usually taken for granted makes it difficult to identify exactly what the trouble is. You tell yourself your community is doing fine.... 
But it makes you mad that people elsewhere, especially in Washington, don't see it that way. ... Their interests are with people who live in cities and don't look like you.... They threaten the way of life you want to preserve. [2] (p. 161)

Finally, Wuthnow determined that many residents of these communities are not simply outraged at the evanescence of their way of life. Some are ideologues and others, partisans, above all other claims. But most residents are pragmatic and when they do not receive the support from Washington, D.C., they believe they deserve, they turn, as the Fallowses also argued, "to local and regional solutions, economic development projects, state government initiatives and technological innovations. Pragmatism is as much about hope as it is about major accomplishments" (Wuthnow 2018, 163-164). Such efforts do not imply a lack of conflict in their communities or a dearth of deep concern about the future of their way of life. To the contrary, in many ways they represent the antithesis of such contentions. We cannot leave this argument, however, without pointing out the irony that many of these populations are strongly supporting government officials whose ideological stance stanchly opposes providing the assistance these citizens nonetheless resent not receiving.

\section{Hochschild's Argument Regarding Moral Community}

Louisiana is one of the poorest states in the United States. It also has been a strong state for the Tea Party, a movement within the Republican Party that calls for lower taxes and reduced government spending [5]. The 60 individuals Hochschild followed intensively in Lake Charles for five years were all adherents of that political movement within the Republican Party. More generally, Louisiana has for some decades been dominated politically by the Grand Old Party (GOP), which fact raised a question for Hochschild: Why do residents of so poor a state vote so overwhelmingly and consistently for officials who campaign on ensuring that they will not receive public nutrition, unemployment support, health care or educational benefits when they may need them? As Hochschild put this conundrum more broadly,

Across the country, red states are poorer and have more teen mothers, more divorce, worse health, more obesity, more trauma-related deaths, more low-birthweight babies, and lower school enrollment. ... Out of the 50 states, Louisiana ranked 49th out of 50 in eighth-grade reading and 49th out of 50 in eighth-grade math. Only eight out of ten Louisianans have graduated from high school, and only 7 percent have graduate or professional degrees [the figure for the authors' state of residence for the last cited statistic, in contrast, is 16.1 percent]. [3] (pp. 8-9)

Given these facts and the challenges they represent, "one might expect people to welcome federal help. In truth, a very large percentage of the yearly budgets of red states-in the case of Louisiana, 44 percent-do come from federal funds: $\$ 2400$ is given by the federal government per Louisianan per year" [3] (p. 9). Nonetheless, Hochschild found that those she followed almost uniformly loathed the national government, even when they or someone in their immediate family had been assisted materially by federal programs. The question for her became ferreting out what factors had created and sustained this paradox, even as the state-led, during the time of her interviews, by a two-term Republican governor-had continued to cut social services and education budgets and offer deeper tax cuts and subsidies to a petrochemical industry that was meanwhile providing fewer jobs at lower compensation levels.

As she delved into how these individuals conceived of their world, she discovered a complex picture quite similar to the one Wuthnow found. First, as she observed, those she interviewed seemed to share what she labeled, "A deep story [or] a feels-as-if story-it's the story that feelings tell, in the language of symbols. It removes judgment. It removes fact. It tells us how things feel" [3] (p. 135). This narrative suggested to her interviewees that their way of life was being undermined by national sympathy-and especially by President Barack Obama's backing- “for line cutters" who were receiving special support, even as their own way of life was threatened. That peril, as their shared story had it, did not come from ongoing corporate pollution of their ecology, or firms' capacity and power to maintain low wages amidst 
rising profitability or the automation of the petrochemical industry. Instead, their narrative assigned responsibility for that condition to the women, minorities, immigrants, refugees—and even (threatened) brown pelicans-receiving special attention from the national government. This perceived outrage was occurring as Hochschild's interviewees saw themselves continuing to stand in an economic line in which they were concerned they never moved forward. Hochschild found that this story, this feeling, was surely true at one level, but its causes were not those that the people accepting it targeted for fury and hatred.

More, the story itself was not of one piece. As she observed,

What I had imagined to be unitary and coherent, I found to be disaggregated into free-standing small narratives.... What these sub-narratives shared, I felt, was the absence of historical context. ... Disaggregated, such smaller narratives hung free, maybe to gather in some new way downstream. And to all this was the background presence of a powerful truth-life had been hard for them and it could get a lot worse. [3] (p. 256)

For these Louisianans, as for the rural residents Wuthnow interviewed across the country, a moral order was crumbling, and they were fearful and anxious. As a result, they were casting about for a story to explain what they saw as the inexplicable, the decline of their way of life. Like many with whom Wuthnow spoke, Hochschild's Louisianans had settled on personalizing their feelings of dread and rage at this condition, in the form of Obama, the nation's first black chief executive, and the national government of which he was symbolic head. For Hochschild, this was not a reasoned judgment or one that accounted for reality, but instead one that decried a changing social order. Those accepting it felt, and therefore believed, that the line-cutter narrative explained that changing context, and the federal government and Obama were its architects and cheerleaders. Part of this fable was true certainly; life had been hard for many rural Louisiana residents in both material and emotional terms in recent generations, but this narrative's focus and claims did not accord with reality and its mix of animus and deep anxiety aimed at the nation was misplaced. In short, its believers' fury was mistargeted and the decline the story purported to "explain" has continued unabated, and perhaps quickened as the attentions of those trusting in this myth have been turned elsewhere.

\subsection{The Role of Race and Ethnicity in Rural Community Imaginaries}

\section{The Fallowses' Argument on Race and Ethnicity}

Apart from visiting a community that had seen an influx of Latinx immigrants to work in its meat processing industry, the Fallowses said little directly about race or ethnicity [1] (pp. 351-370). What they said about that locality, however, was instructive, as they stressed the pragmatism of its population's response to that influx, even as a large share of the community (67 percent) voted for Donald Trump and his anti-immigration agenda in 2016; "Put another way, in communities like those in western Kansas, whose economic vitality today and demographic prospects for tomorrow depend on attracting new residents, people have worked out a modus vivendi that resembles ethnic change through America's past" [1] (p. 358).

Similarly, the authors approvingly quoted a farm industry executive who offered the following assessment of the situation in Dodge City, Kansas:

Dodge City has found a way to make this work. No one fought it in the schools. I'm a pretty conservative guy, but I think we have to keep finding a better way to integrate this diverse population into our economy. If I say it in conservative circles, I might run the risk of somebody heating up the pot of tar, to tar and feather me, but it's the reality of our town. [1] (p. 361)

Thus, despite the prejudice and conflict to which their interviewee's allusion to a horrific historic practice pointed, the Fallowses' view is that the communities they had visited that "were succeeding" had overcome any latent challenges linked to race and ethnicity and were moving pragmatically forward. There is, in their argument, no trace of concern about how rage against government allowing 
the decline of the moral community by permitting an invasion of others, or ire at line cutters, could undermine efforts to secure social and economic change. Perhaps this was so because the meat industry has offered steady employment options for Dodge City's immigrants, and because almost no native-born Americans work in those plants. Or perhaps Dodge City residents really are cognitively able to support elected leaders who rail against those who require public assistance of any sort and ignore the fact that so many such individuals live peaceably and productively in their midst. In any case, we note that this nation's past "modus vivendi" regarding immigration and race is replete with just the sort of horrors to which the Fallowses' interviewee alluded.

\section{Wuthnow's Argument Regarding Race and Ethnicity}

Wuthnow argued that race and ethnicity played a central part in his interviewees' concerns about the perceived decline of their moral community. He visited and specifically highlighted Garden City, Kansas, a community located 58 miles from Dodge City, about which he had written previously [6]. As he recounted in his more recent book, however, "On 14 October 2016, the FBI arrested three right wing militants who were plotting to bomb an apartment building in Garden City Kansas, killing dozens of immigrant Somali meatpacking plant workers and hoping to initiate a blood-bath against immigrants across the nation" [2] (p. 141).

Echoing the Fallowses' contention concerning Dodge City, Wuthnow noted that Garden City, also a meatpacking town, had previously integrated its newcomers fairly well. But he also suggested, in contrast to their argument, that this incident raised a question, "The fact that a bombing plot could be hatched in the same community necessitates asking pointed questions about the role of inflamed political rhetoric in emboldening bigotry and violence" [2] (p. 142).

Wuthnow summarized his findings regarding race and ethnicity by suggesting that they were of a piece with his argument concerning rural dwellers' perception that their way of life was being compromised by outside forces, too often countenanced and supported by the national government:

Racist attitudes toward African-Americans among the larger population of white rural Americans are best summarized the way the Hispanic mayor of Garden City did-people don't come right out and say it, but there is a lot of prejudice. The implicit prejudice surfaced most often under the rubric of riff raff. ... [who] could be anybody-white Anglo, Hispanic, or African American - but in communities where there were any African Americans, they were the implied referent. The trouble with riff raff ... was also that they were receiving special privileges from the government because of who they were. [2] (pp. 152-153)

To illustrate this propensity, Wuthnow cited one of his interviewees expressing a central contention of the organizing fable of the federal government and unwanted individuals as the "others" responsible for a usurping and negative change in the moral character of his community, "I don't think the government just owes you something because you know how to beat the system. I know a lot of minorities and they know how to work the system. They're riding around in expensive vehicles and I'm paying for their kids' lunch!" [2] (p. 153).

\section{Hochschild's Findings Concerning Race and Ethnicity}

Like Wuthnow, Hochschild argued that the issue of race was central for those she interviewed. However, she also contended that the origins of her interviewees' angst regarding supposed line cutters was not always simply a case of racism, understood as a classical hatred of an "other" bound up in a belief in one's innate superiority or that individual's inferiority. As Hochschild framed the concern:

In this book, I describe racism as a 'belief in a natural hierarchy that places blacks at the bottom, and the tendency of whites to judge their own worth by distance from that 'bottom.' Of the sixty people I interviewed, many tacitly agreed with this. Others believed, or seemed to want to believe, that there was no such hierarchy or way of judging worth, and that we live in a race blind society. But a good number also believed that many fellow Americans do still live with the idea of such a hierarchy, but that this is in no way natural or good. [3] (p. 254) 
Race was key for these Tea Party members, although not always in an absolute and clear way. Indeed, race was often tied to arguments concerning social class, religion and gender as well. Women, minorities of all sorts, but especially blacks, were line cutters for Hochschild's interviewees and all were targets of disdain and anger, but not all generated consistent amounts of ire:

Along with blacks and immigrants, women were also 'line cutters,' although in men's minds, women tended to divide into separate mental categories, daughters ..., wives or partners. ... and potential rivals at work. ... So, race, class, national identity, religion, region, views of gender and sexual orientation-all these joined to reinforce a sense that outside of Louisiana, too, a precious way of life, like the nation itself, was being left behind. [3] (pp. 258-259)

Another way to put this point is to suggest that the deep story had been adopted by all of the Tea Party devotees with whom Hochschild interacted, but that narrative also included multiple forms of anxiety and anger and those in turn were mediated, to varying degrees, by other factors, including kinship and familiarity. For some of Hochschild's interviewees, classical racism stood as the single most important of these valences. For others, race as a factor was joined by other economic and social anxieties to produce a potent combination resulting in self-righteous wrath. Importantly, their anger did not depend on the relative proportion of the individuals they perceived as undeserving in their midst. More, it did not acknowledge that many in their own families were receiving succor from one central target of their ire. Instead, this deep story represented an effort to maintain their conception of a moral community in which those like them occupied the top rung of an always present, if not always explicitly articulated, racialized social hierarchy.

As with Wuthnow, for Hochschild, if race was not always the foremost or determining variable leading to othering and scapegoating, it nevertheless was always a primary factor in the mix. Meanwhile, fear that racial others might soon eclipse one's social standing, understood as a way of life or being in the world, was a key fuel for what became the Tea Party members' loathing of the federal government and of the nation's broader social imaginary as innately inimical to their own.

We emphasize here, as did Hochschild and Wuthnow, that this virulent and absolutist anger was not deserved and that the deep story used to explain the decline of these individuals' beloved moral communities bore little relationship to reality. But narratives need not be factual to prove powerful; they need only provide a graspable account of who or what caused one's anxiety and anger. Race, always a factor shaping social life throughout the United States, but especially so in the South, has played a lead role in such stories in rural America today. It is doing so on the basis both of perceived innate differences and a long history of ascribed characteristics and socially sanctioned cruelties targeted to minorities.

Table 1 captures the main themes of each of the volumes we treat here: 
Table 1. Summary of the main themes of the reviewed books.

\begin{tabular}{|c|c|c|c|}
\hline Books & $\begin{array}{l}\text { Our towns: a } \\
100,000 \text {-mile journey } \\
\text { into the heart of } \\
\text { America by Fallowses }\end{array}$ & $\begin{array}{l}\text { The left behind: decline and rage in rural } \\
\text { America by Wuthnow }\end{array}$ & $\begin{array}{l}\text { Strangers in their own land: } \\
\text { anger and mourning on the } \\
\text { American right by } \\
\text { Hochschild }\end{array}$ \\
\hline Observations & $\begin{array}{l}\text { Regardless of } \\
\text { disagreements about } \\
\text { national politics, people } \\
\text { in small towns are } \\
\text { working together } \\
\text { towards local } \\
\text { possibilities. }\end{array}$ & $\begin{array}{l}\text { Rural citizens across the United States } \\
\text { perceive themselves as under attack from } \\
\text { the outside and that perception has sharply } \\
\text { deepened racial, cultural and partisan gaps. }\end{array}$ & $\begin{array}{l}\text { Fueled by conservative media } \\
\text { and targeted corporate } \\
\text { advocacy campaigns, there is } \\
\text { an increasing angst among Tea } \\
\text { Party sympathizers towards } \\
\text { the national government. The } \\
\text { attitude has proved } \\
\text { counterproductive in } \\
\text { addressing the socioeconomic } \\
\text { problems of such } \\
\text { communities. }\end{array}$ \\
\hline Solutions & $\begin{array}{l}\text { Pragmatic interventions } \\
\text { and partnership } \\
\text { building. }\end{array}$ & $\begin{array}{l}\text { Conflict amelioration and management in } \\
\text { addition to socially conscious mobilization } \\
\text { for action. }\end{array}$ & $\begin{array}{l}\text { Compassionate listening to } \\
\text { bridge the "empathy wall" } \\
\text { between those with differing } \\
\text { values. }\end{array}$ \\
\hline $\begin{array}{l}\text { Moral Community } \\
\text { Assumptions }\end{array}$ & $\begin{array}{l}\text { Hoping that the rural } \\
\text { citizenry will at some } \\
\text { point demand that their } \\
\text { public leaders adopt an } \\
\text { alternate course that } \\
\text { employs political power } \\
\text { more effectively to } \\
\text { regulate economic } \\
\text { institutions. The authors } \\
\text { do not explain why and } \\
\text { how. }\end{array}$ & $\begin{array}{l}\text { A common perspective concerning the } \\
\text { plight of rural communities, moral outrage. } \\
\text { "The moral outrage of rural America is a } \\
\text { mixture of fear and anger. The fear is that } \\
\text { small town ways of life are disappearing. } \\
\text { The anger is that they are under siege ... It } \\
\text { stems from the fact that the social } \\
\text { expectations, relationships, and obligations } \\
\text { that constitute the moral communities they } \\
\text { take for granted and in which they live year } \\
\text { by year are being fundamentally fractured" } \\
\text { [2] (p. 6). } \\
\text { Most residents are pragmatic and when } \\
\text { they do not receive the support from } \\
\text { Washington, D.C., they turn to local } \\
\text { solutions, even as they realize those will } \\
\text { likely be insufficient alone to address their } \\
\text { challenges. }\end{array}$ & $\begin{array}{l}\text { The interviewees perceived } \\
\text { their way of life was being } \\
\text { undermined by national } \\
\text { sympathy, "for line cutters" } \\
\text { who were receiving special } \\
\text { support. } \\
\text { Locals' fear and anxiety } \\
\text { because of their perception of a } \\
\text { moral order that is crumbling } \\
\text { has led them to mistarget those } \\
\text { they blame for their situation. }\end{array}$ \\
\hline $\begin{array}{l}\text { The role of race and } \\
\text { ethnicity in rural } \\
\text { community imaginaries }\end{array}$ & $\begin{array}{l}\text { The Fallowses said little } \\
\text { directly about race or } \\
\text { ethnicity. They claimed } \\
\text { that communities they } \\
\text { visited had overcome } \\
\text { any latent challenges } \\
\text { linked to race and } \\
\text { ethnicity and were } \\
\text { moving forward } \\
\text { pragmatically. }\end{array}$ & $\begin{array}{l}\text { His interviewees expressed a central } \\
\text { contention of the organizing fable of the } \\
\text { federal government and unwanted } \\
\text { individuals as the "others" responsible for a } \\
\text { usurping and negative change in the moral } \\
\text { character of their community. }\end{array}$ & $\begin{array}{l}\text { The origins of her interviewees' } \\
\text { angst regarding supposed line } \\
\text { cutters was not always simply } \\
\text { a case of racism, understood as } \\
\text { a classical hatred of an "other" } \\
\text { bound up in a belief in one's } \\
\text { innate superiority or that } \\
\text { individual's inferiority. } \\
\text { Nevertheless, it rested on an } \\
\text { implied racial hierarchy and } \\
\text { its dissolution had created } \\
\text { deep unease and anger among } \\
\text { those she studied. }\end{array}$ \\
\hline
\end{tabular}

\section{Discussion: Considering the Fallowses, Wuthnow and Hochschild Arguments in the Context of Central Appalachia}

One of the communities in which we have worked is located in Central Appalachia in West Virginia. That town of roughly 2000 people has seen its major economic drivers decline markedly in the last three decades. Its population had long depended on coal mining, which has now all but ceased in the community's vicinity, and on a branch campus of a higher education institution, which closed three years ago. The jurisdiction's population and physical infrastructure, respectively, have rapidly decreased and deteriorated as a result of these major changes. Meanwhile, the community has suffered from an accompanying opioid addiction crisis and uptick in petty crime, amongst a share of its citizens seeking to support that habit.

We have facilitated a stakeholder dialogic process aimed at assisting the town's public leaders and groups of its citizens to imagine a fresh future for their community, accompanied by different forms of economic activity. We have also sought to support these townspeople as they rank ordered actions to 
secure the future they envisioned and to develop concrete strategies aimed at securing it, including constructing viable multi-stakeholder partnerships.

The other Appalachian town we have sought to assist for nearly three years is located in Virginia in the state's traditional coal producing area. It, too, has a population of approximately 2000 individuals. The principal economic drivers on which this community had long-relied have collapsed in recent decades, including coal mining and tobacco production. As with the West Virginia jurisdiction noted above, we have sought to help this town's leaders and groups of its citizens develop clear ideas for what its future might be and to identify plans and strategies to secure their realization. As with our efforts in West Virginia, we have worked to assist this community's citizens to develop viable cross-sector partnerships to address their articulated priorities.

As was true of a significant share of the rural communities nationally in which Wuthnow undertook his research, and was the case for Hochschild's interviewees in Louisiana, the voters of the counties in which we have been working provided President Donald Trump large majorities in the November 2016 election. (2016 Louisiana Presidential Election Results, St. Charles Parish, 63.5 percent [7]; 2016 Virginia Presidential Election Results, 80.6 percent [8]; 2016. West Virginia Presidential Election Results, 67.6 percent [9].) Trump campaigned for office blaming immigrants and the national government for the economic woes of the region and arguing that he would immediately return previous levels of prosperity to the coal communities of Appalachia [7]. While he has not done so to date, and any fact-based analysis suggests he is unlikely to do so in the near future, that reality hardly matters for super-majorities of the voters of these towns who support the narrative he has offered to explain their communities' woes.

Trump's rhetoric has hewed closely to Hochschild's deep story and Wuthnow's perceived decline of moral community argument, and it therefore has both fed and offered an endorsement of those narratives. In this respect, and in our experience as participant observers working in these two towns, the debate regarding whether "coal can return" has not ended, with many citizens willing to engage in a measure of magical thinking in the hope that their way of life, including its relative prosperity and, more deeply, organizing racial social ordering, can return. This has taken the guise of strong majorities for other GOP candidates in addition to Trump who, as Hochschild reported had occurred in Louisiana, has blamed the national government (via environmental regulation particularly) for that area's economic problems and suggested that immigrants had to be stopped from stealing native-born Americans' jobs [10]. As we noted above, those officials have meanwhile sanctioned tax cuts for wealthy individuals and service reductions to constituents, arguing that industry needs those steps to provide such employment as remains or to bring jobs back. The result to date has been deepening fiscal distress for these jurisdictions and rising social and health problems for their populations, already suffering economically and losing residents. Neither locality in which we work has experienced a resurgence in employment.

The version of Hochschild's deep story in the towns we have sought to assist has resulted in continuing socially sanctioned discrimination against blacks, whom we have heard described by one town official, in an echo of Wuthnow, as "riff raff" and disproportionately responsible for that jurisdiction's crime. This epistemic-scale narrative of anger and anxiety about unnamed others who were inexplicably and unfairly attacking a long-known way of life must be addressed and successfully overcome when leaders seek to assemble political coalitions for possible adaptive experimentation with new strategies for their economies or for building social capital.

As a result, it has often been difficult for interested townspeople and their leaders to attain change in policies or direction in both towns. We have also found that, consonant with Wuthnow and Hochschild's findings, community leaders seeking to secure coalitions for change had to manage continuing conflict concerning whether and how the towns should change at all, despite the obvious economic and social challenges besetting them, in addition to squabbles concerning how best to implement such steps as might be envisioned. This has occurred as national, state and local GOP leaders have promised that the communities' cherished traditional way of life and its associated social hierarchy and prosperity would shortly return without the need for change. In short, epistemic unease 
and divisions have fed abiding controversy concerning any and all strategies to address both shortand long-term decline in the Appalachian towns in which we have worked.

Indeed, we have come to view this reality as something of a cultural penumbra that those seeking change must navigate in these communities. That is, continuing dread and anger about the decline of a way of life in these localities colors and suffuses all possibility for change. Officials and townspeople alike must address that deeper level of concern as they develop and work to adopt and implement steps for change. Yet none of these challenges, as large as they are for the town leaders and citizens with whom we have worked, have prevented at least a share of those individuals from recognizing that their ways of life cannot, and perhaps should not, endure as traditionally understood. In this sense, the behaviors and actions of this active group in each of the towns in which we work has evidenced the pragmatism that the Fallowses found among many local officials they interviewed. We have certainly counted on that reasonableness as we have worked with leaders. But while that orientation is both essential and deeply admirable, it is not alone sufficient or sufficiently broad without a companion sensitivity to the deeper currents and conflict at play in these communities, as Wuthnow's and Hochschild's works emphasized, and those we have worked alongside have illuminated.

\section{Conclusions}

Taken together, our experience working with two Central Appalachia communities and their residents, illustratively recounted here, closely aligns with the principal findings of the three volumes discussed here. Leaders in each Appalachian town are working with populations that have largely accepted the deep story of "line cutters" and the national government as responsible for the decline of their ways of life and knowing. Those residents evidence fear and anxiousness about those shifts and their responses reveal the implicit and explicit conceptions of racialized social hierarchy so much a part of Hochschild's and Wuthnow's findings and analyses. Residents have made sense of an almost cataclysmic pace and scale of economic and social change in their towns by adopting scapegoating and blame-casting behaviors. That anxiety and anger have arisen as a result of an almost incomprehensible shift in reality versus previous lived experience and the conflict and tensions arising from that fact now permeate, and will continue to mediate all efforts to secure change in the towns in which we have been privileged to work.

None of this is to say that many individuals in these communities are not working for change or are accepting false arguments that the status quo ante will soon return. In short, our experience also accords with the Fallowses' conclusion that many citizens and leaders of these towns are thoroughly pragmatic and have embarked on doing whatever they can to address the forces threatening their communities. What they are not doing, however, is pressing those efforts apart from the deeper conflicts now roiling their populations. They cannot simply set aside the abiding anxiety and rage of many of their fellow citizens concerning the decline of their traditional way of life. They must instead attempt to manage that angst on a daily basis by seeking to build and rebuild political coalitions for change while addressing the many layers of conflict that accompany their efforts to do so.

These realities suggest the aptness of the Indian fable of the blind men and the elephant as a guiding metaphor for those seeking to assist rural communities to cope with the momentous economic and social shifts many are today confronting. First, those desirous of assisting these jurisdictions must recognize the continuing difficulties their residents address in coming to grips with forces that have constituted an assault on their most basic epistemic, and even ontological, assumptions about their lives. Second, the origins of those trends are both different and far more complex than those assigned by the deep story of line cutters and malevolent governance accepted by many of these townspeople. Third, this reality demands, as Hochschild argued, that those working with individuals in these communities practice a deep empathy for the hard work those residents must undertake in these terms, even as they seek to assist them with the design and implementation of strategies for change. That empathy need not, and cannot, however, condone a dominant social narrative largely 
disassociated from reality. It is nonetheless essential to dignify those wrestling with the realities of calamitous change.

Finally, the research treated in the three volumes we review here and our own briefly shared illustrative experience of working for change in two small Appalachian jurisdictions suggest that would-be community developers in struggling rural areas must seek to consider the entire "elephant." In particular, they should not imagine that simply concentrating on the pragmatic pursuit of partnerships or technical assistance alone will prove sufficient to help these populations to imagine fresh possibilities and undertake the steps to realize them. In sum, all three of the works treated here offer important facets of community that citizens, professionals and investigators alike must consider and address when working for change. Together, these studies provide a holistic portrait of the character of the community development challenge for these jurisdictions. They also caution those who would seek to help rural towns with development efforts that their challenges are as often cultural as economic and, in any case, may not be successfully addressed in the absence of a shift in these communities' social imaginaries. That goal in turn demands deep social learning and will not occur on the basis of technical interventions alone.

Author Contributions: M.S.J., Conceptualization, supervision, writing, review and editing; B.A.-L., resources, writing, review and editing, L.N., project administration, resources, writing, review and editing; N.M., writing, reviewing and editing. All authors have read and agreed to the published version of the manuscript.

Funding: This research received no external funding.

Conflicts of Interest: The authors declare no conflict of interest.

\section{References}

1. Fallows, J.M.; Fallows, D. Our Towns: A 100,000-Mile Journey into the Heart of America, 1st ed.; Pantheon Books: New York, NY, USA, 2018.

2. Wuthnow, R. The Left behind: Decline and Rage in Rural America; Princeton University Press: Princeton, NJ, USA, 2018.

3. Hochschild, A.R. Strangers in Their Own Land: Anger and Mourning on the American Right; The New Press: New York, NY, USA, 2018.

4. Goldbard, A. The Culture of Possibility: Art, Artists \& the Future; Waterlight Press: Minneapolis, MN, USA, 2013.

5. Montopoli, B. Tea Party Supporters: Who They Are and What They Believe. CBS Interactive Inc. 14 December 2012. Available online: https://www.cbsnews.com/news/tea-party-supporters-who-they-are-and-what-theybelieve/ (accessed on 12 August 2019).

6. Wuthnow, R. Remaking the Heartland: Middle America since the 1950s; Princeton University Press: Princeton, NJ, USA, 2011.

7. 2016 Louisiana Presidential Election Results. Available online: https:/www.politico.com/2016-election/ results/map/president/louisiana/ (accessed on 12 August 2019).

8. 2016 Virginia Presidential Election Results. Available online: https:/www.politico.com/2016-election/results/ map/president/virginia/ (accessed on 12 August 2019).

9. 2016 West Virginia Presidential Election Results. Available online: https://www.politico.com/2016-election/ results/map/president/west-virginia/ (accessed on 12 August 2019).

10. Stolberg, S.G. Trump's Promises Will Be Hard to Keep, but Coal Country Has Faith. The New York Times. 28 November 2016. Available online: https://www.nytimes.com/2016/11/28/us/donald-trump-coal-country. html (accessed on 18 August 2019).

(C) 2020 by the authors. Licensee MDPI, Basel, Switzerland. This article is an open access article distributed under the terms and conditions of the Creative Commons Attribution (CC BY) license (http://creativecommons.org/licenses/by/4.0/). 